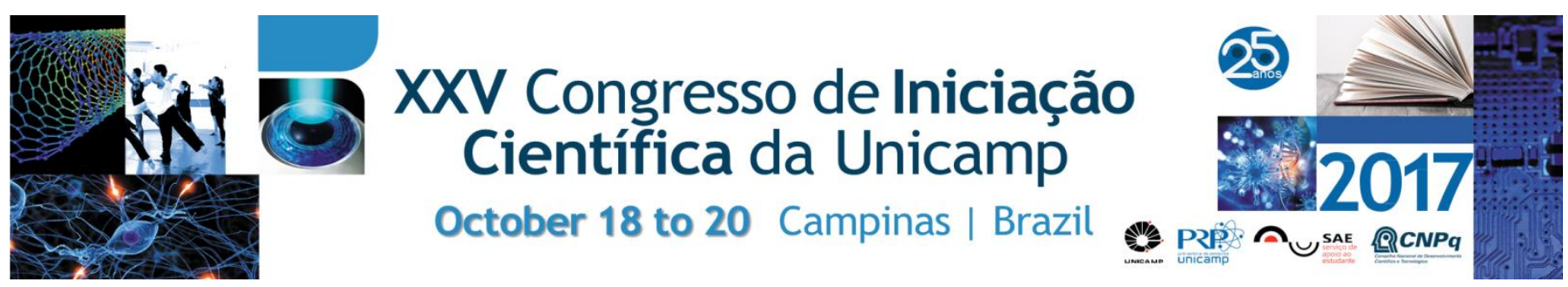

\title{
Recovery of the Laklãnõ/Xokleng origin myth registered by Wanda Hanke
}

\author{
Beatriz Furlan Toledo*, Wilmar da Rocha D'Angelis.
}

\begin{abstract}
The goal of this project is to recover a mythical narrative about the origin of the Xokleng people in order to make it available for future linguistics studies. The chosen text is part of the study called "Apuntes sobre el idioma Caingangue de los Botocudos de Santa Catarina, Brasil" and it is a mythical narrative written in the Xokleng language registered by the Austrian researcher and indigenist Wanda Hanke. This study was published by the Museu Paranaense in 1947. The original narrative does not contain any glosses within it. It is just a general translation and a short vocabulary, which is incomplete. Therefore, a significant part of this work is properly glossing the text and translating each sentence of the original text (with support from other texts and vocabularies available in Xokleng). Henceforth the translation to Brazilian Portuguese of such text (originally written in Xokleng before the contact of other languages) will be available for the general public.
\end{abstract}

Key words: Myth, Xokleng, Wanda Hanke.

\section{Introduction}

In the 40s the Austrian researcher Wanda Hanke went through the indigenous areas of the Brazilian states of Paraná and Santa Catarina registering ethnographic and linguistic information.

Among the communities that she has visited was the Xokleng/Laklãnõ people (known, in the past, as Botocudos), in east Santa Catarina.

This people had less than 30 years of friendly contact with the national Brazilian society, considering that the first contact was made in 1914 by SPI (Serviço de Proteção aos Índios). Wanda Hanke had the opportunity of listening and registering the ritual in which the Xokleng people presented their origin myth. She published this mythical narrative in the sixth volume of Arquivos do Museu Paranaense (Hanke 1947). The original text does not contain glosses, just a general and free translation plus a small and incomplete vocabulary.

The main goal of this project is the recovery of this mythical narrative registered in the Xokleng language that used to be told orally before they had contact with other languages; and making it accessible to both the Xokleng community and the general public.

\section{Results and Discussion}

The steps to recovery the original myth of the Xokleng people were : i) preparation of the corpus; ii) studying the Xokleng language (syntax, phonology) iii) identifying and glossing all the words in the text; iv) update all the words to the current Xokleng ortography and v) proposing a translation for all paragraphs.

As a source of lexical data, the materials used were: Hanke(1947), Gakran (1997), Jolkesky (2010) and Alves (2014). Also, as part of the study of the Xokleng language I translated the article The Kaingáng Language written by Jules Henry in 1948.

La Genesis de los Caingangues de Sta Catarina, Brasil with gloss, updated orthography and translation (extract)
Nunk ê-ngrá unk ka ngoyo mbagn dsyly ka CJ to-celebrate CJ PREP water big shore PREP

kũ ẽ-glá* ũg ka goj bág zyl ka

nunk kulo to kan-ngra ne ianglo.

CJ field SM to-celebrate ASP first-men

nũg* kulõ tõ kan-glá* nẽ jãnglo*

The first men were celebrating in the shore near the lake and the field.

\section{Conclusions}

This research pursues to present a linguistic study about the Xokleng language made from an oral and mythical narrative of these people located in the Brazilian state of Santa Catarina. All the linguistics' studies about the Xokleng language were made mostly just based in simple and elicited sentences. However, the present study allows the analysis of the language in a natural context (during an especial ceremony of the people) and also before the spreading of bilingualism among the community. That makes possible a comparison between the language spoken today by the Xokleng and the language before the contact with the Brazilian society.

\section{Acknowledgement}

I am thankful for the financial support from FAPESP (Proc. 2016/14631-0) and for the opportunity to be mentored by my adviser Prof. Wilmar da Rocha D'Angelis.

1 GAKRAN et al (1997), Vocabulário. In Nanblá Gakran (Org.), Ãg vẽ tẽ káglẽl mũ - Nosso idioma reviveu. São Leopoldo: COMIN-IECLB, p. 47-52.

2 HANKE, W. Apuntes sobre el idioma Caingangue de los Botocudos de Sta. Catarina, Brasil. Arquivos do Museu Paranaense, vol. VI. Curitiba, 1947, p. 61-97.

3 HENRY, J. (1948). The Kaingáng Language. International Journal of American Linguistics, 14, (3), p.194-204 